livraisons

d'Histoire

de l'Architecture

\section{Livraisons de l'histoire de l'architecture}

24 | 2012

Le phare et l'architecte

\title{
Le phare-mobile : projet pour Le Port de Paris 2010
}

"Talk with Jure Kotnik"

"Gespräch mit Jure Kotnik »

\section{Jure Kotnik}

Traducteur : Vincent Guigueno

\section{(2) OpenEdition}

\section{Journals}

Édition électronique

URL : http://journals.openedition.org/lha/105

DOI : $10.4000 /$ /ha. 105

ISSN : 1960-5994

\section{Éditeur}

Association Livraisons d'histoire de l'architecture - LHA

\section{Édition imprimée}

Date de publication : 19 décembre 2012

Pagination : 183-186

ISSN : 1627-4970

\section{Référence électronique}

Jure Kotnik, «Le phare-mobile : projet pour Le Port de Paris 2010 », Livraisons de l'histoire de

l'architecture [En ligne], 24 | 2012, mis en ligne le 16 avril 2015, consulté le 20 avril 2019. URL : http:// journals.openedition.org/lha/105; DOl : 10.4000//ha.105

Ce document a été généré automatiquement le 20 avril 2019.

Tous droits réservés à l'Association LHA 


\title{
Le phare-mobile : projet pour Le Port de Paris 2010
}

\author{
"Talk with Jure Kotnik" \\ « Gespräch mit Jure Kotnik» \\ Jure Kotnik \\ Traduction : Vincent Guigueno
}

NOM DU PROJET : MOBILE LIGHTHOUSE

ARCHITECTES : ARHITEKTURA JURE KOTNIK (www.jurekotnik.com)

ÉQUIPE DE DESIGN : JURE KOTNIK, GERARD NOIROT

LOCALISATION : PARIS, FRANCE

CLIENT : PORTS DE PARIS

NOMBRE DE CONTAINERS : 4

TAILLE : $15 \mathrm{~m} 2$

ANNÉE : 2010

PHOTOGRAPHIE : PORTS DE PARIS

1 Le phare mobile a été commandé en 2010 pour commémorer le $40^{\mathrm{e}}$ anniversaire du port de Paris. Il a été conçu par Gérard Noirot et Jure Kotnik, architecte slovène qui utilise les containers dans son travail ${ }^{1}$. Les activités du port de Paris sont méconnues du grand public. Pourtant, avec 20 millions de tonnes de marchandises et 7 millions de personnes transportées par voie d'eau, le port de Paris est le plus grand port fluvial en France et le deuxième en Europe. La promotion du transport fluvial comme mode écologiquement durable était l'un des objectifs du projet de phare mobile. Le transport annuel sur les rivières de Paris opéré par le port représente un million de camions en moins sur les routes, soit une réduction de 200.000 tonnes des rejets de $\mathrm{CO} 2$. Le phare mobile en container devait symboliquement «éclairer » ces faits, en fonctionnant pendant une période de trois mois dans les paysages de cinq sites portuaires de la Seine et de la Marne (Évry, Limay, Paris, Gennevilliers et Bonneuil-sur-Marne). 
III. 1 : J. Kotnik Coupe, plan et élévations pour un phare de Paris en containers, 2010
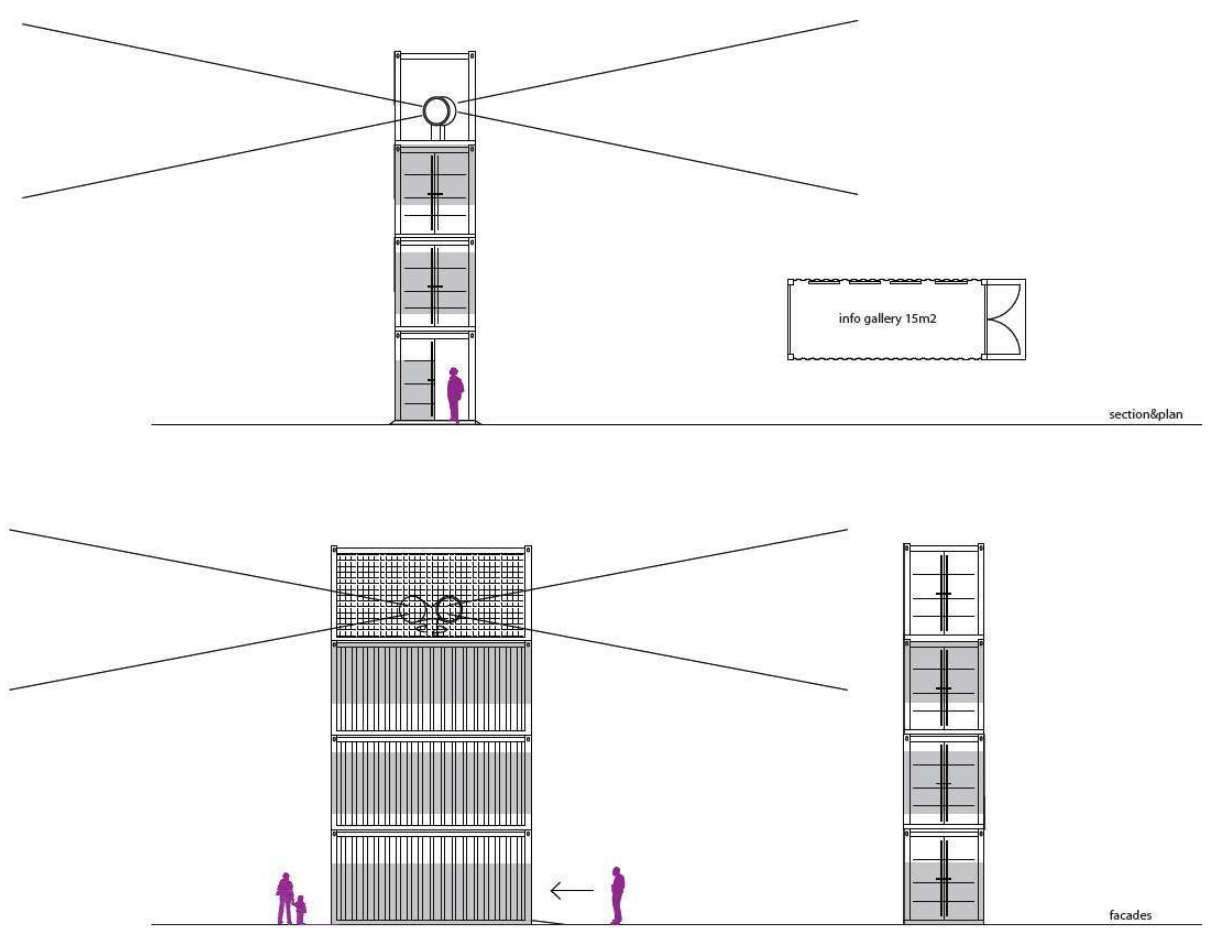

Cl. Arhitektura Kotnik Office

III. 2 : J. Kotnik, Schéma de conception

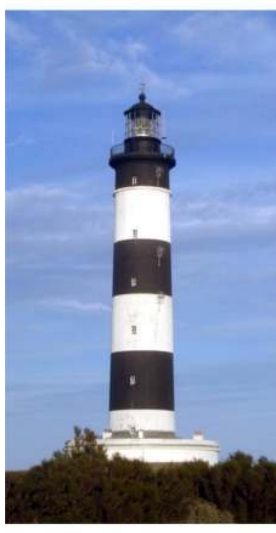

tradition

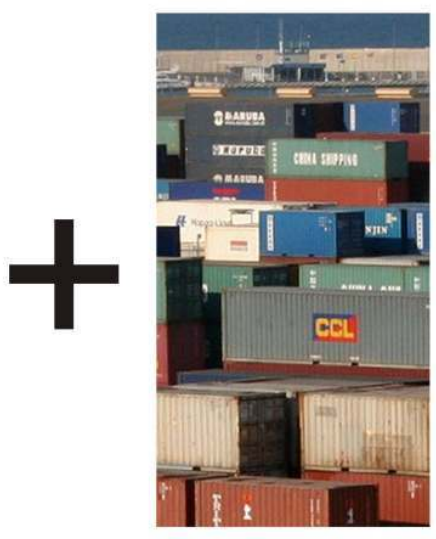

containers

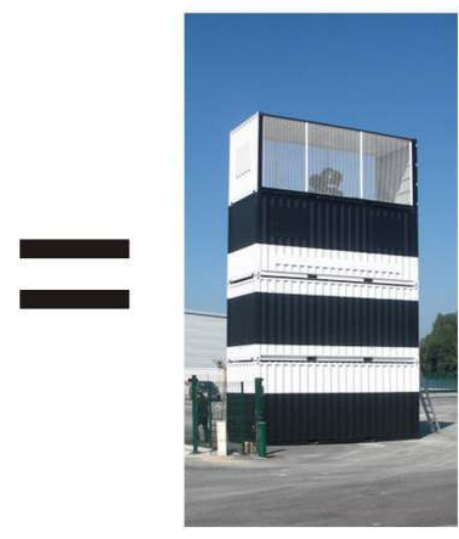

mobile lighthouse

Cl. Arhitektura Kotnik Office 
III. 3 : Mise en place des éléments sur le quai du port de la Rapée

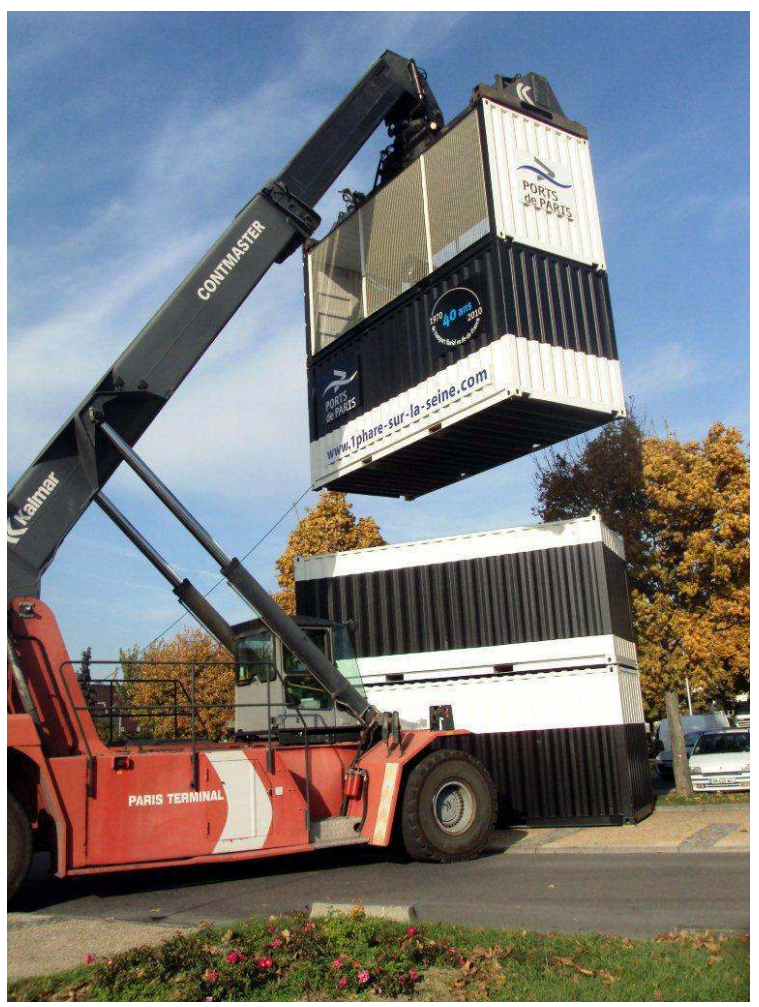

Cl. Ports de Paris

III. 4 : Affiche annonçant la mise en service du phare

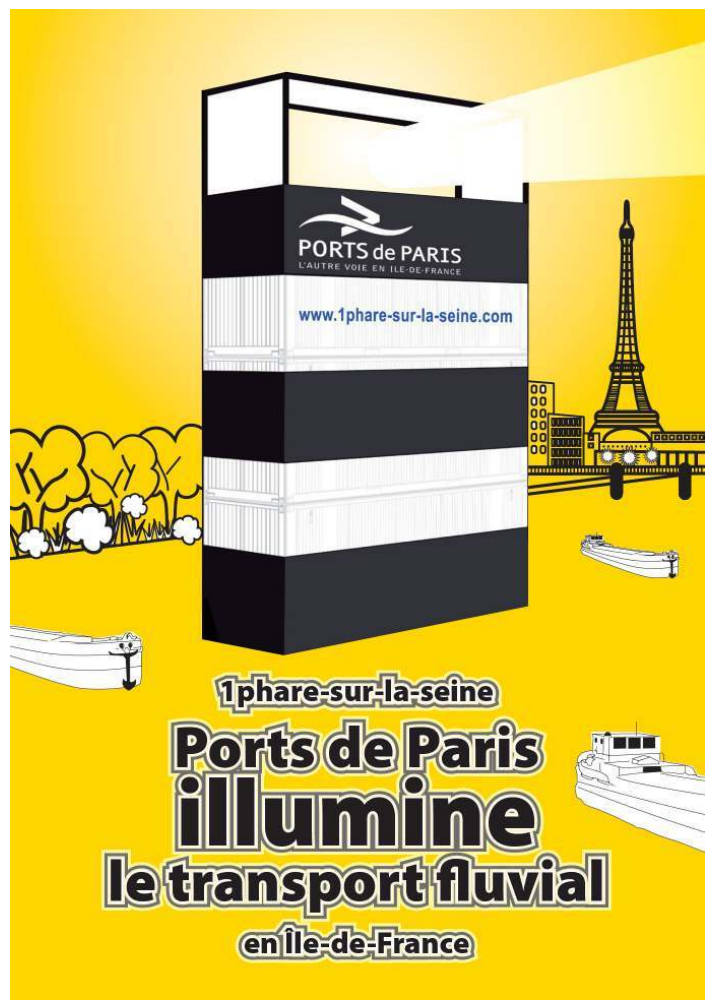

Cl. Ports de Paris 
2 Le phare mobile combine deux éléments de base du port: le phare «traditionnel » et les containers. Les phares constituent l'un des symboles les plus marquants du transport maritime et se retrouvent dans tous les ports. Les containers sont les symboles des ports modernes, étant l'un des éléments principaux de transport contemporain. Ils sont aussi un matériau idéal pour construire une architecture événementielle. Ils sont faciles à construire et à déplacer d'un site à un autre. Quatre conteneurs de 20 pieds ont été recyclés formant un phare haut de 10 mètres. Le container supérieur possède deux feux de croisement en rotation, tandis que le rez-de-chaussée abrite un bureau contenant des informations sur les activités portuaires dans la région parisienne et le transport fluvial comme alternative au transport routier.

\section{5 : Vue du phare de Paris la nuit sur le quai du port de la Rapée}

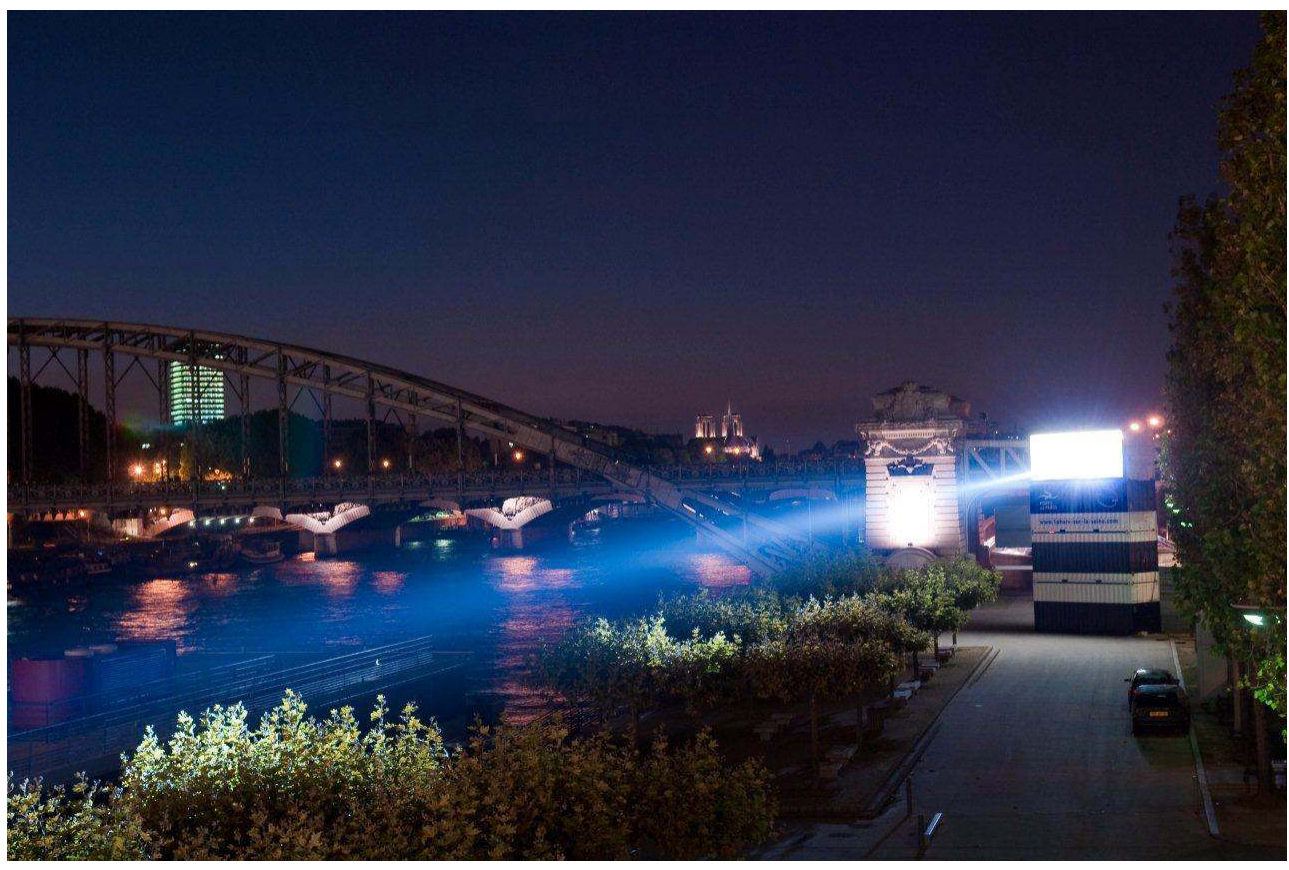

Cl. Ports de Paris 
III. 6 : Vue du phare de Paris la nuit depuis le quai du port d'Austerlitz

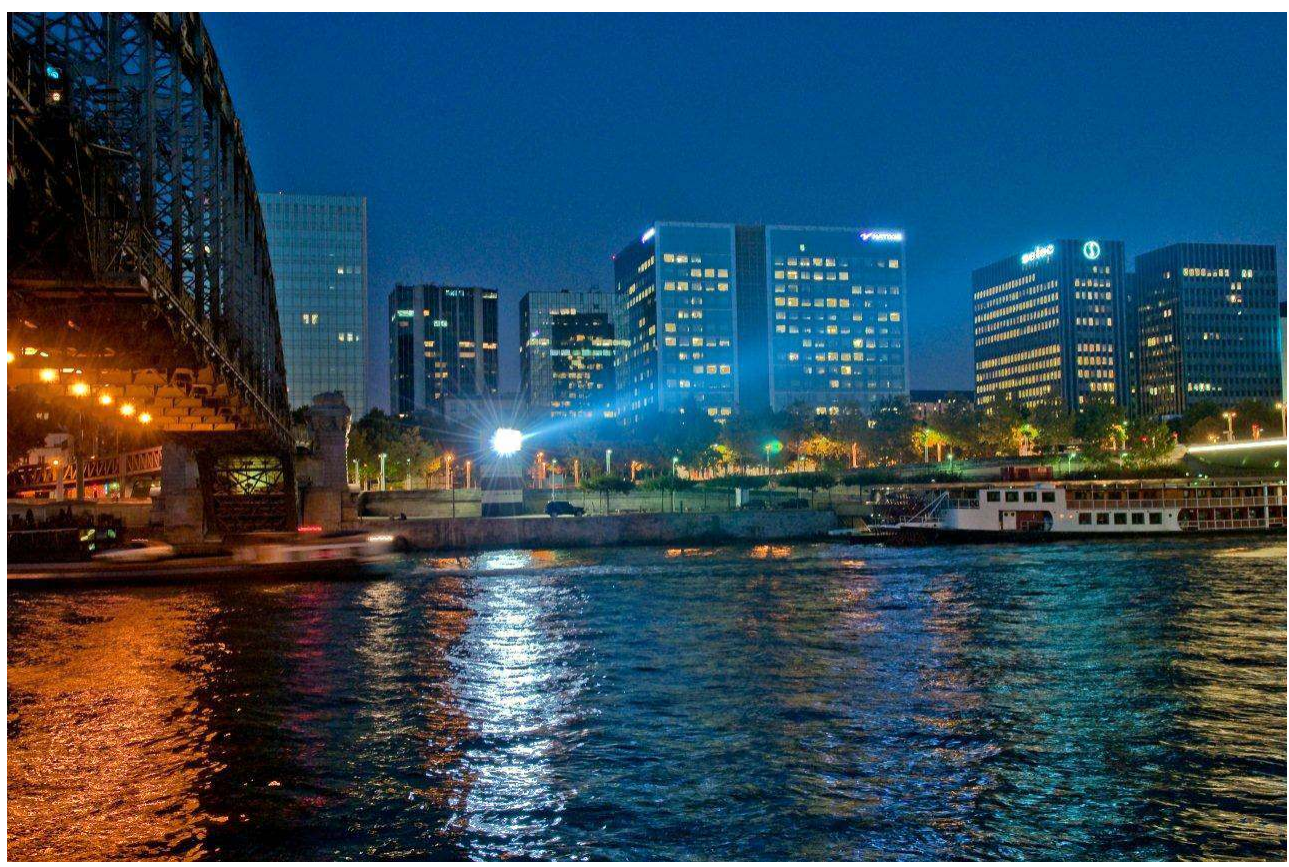

Cl. Ports de Paris

\section{NOTES}

1. Jure Kotnik, Architecture de containers, Links Books, 2008.

\section{RÉSUMÉS}

Mobile lighthouse was designed to commemorate the $40^{\text {th }}$ anniversary of the Paris port and to bring closer its activities to a broader audience. Port is not a thing that most people would associate when mentioning Paris but with its 20 million tons of cargo and 7 million people transported by water Paris port is the biggest inland port in France and second biggest in Europe and one of the aims of this lighthouse was a promotion of the fluvial transport as an environmental sustainable type of transport. Yearly transport on the rivers conducted by Paris port means one million fewer trucks on the roads and doing so, 200000 tones $\mathrm{CO} 2$ are saved. Container mobile lighthouse was, also symbolically, illuminating those facts, enlightening the visitors and surroundings of five different port locations along the rivers Seine and Marne (Ports of Evry, Limay, Paris, Gennevilliers and Bonneuil-sur-Marne) for a period of three months. 
The design of the mobile lighthouse connects two basic port elements, a traditional lighthouse and containers. Lighthouses are one of most notable symbols of nautical transport and can be found in all traditional ports. Containers on the other hand are the symbol of the modern ports being one of the main transport elements, but also at the same time they are a perfect material to construct event architecture. They are accessible, they allow mobility and are easy to be constructed and re-set again on some other location. Four recycled 20 -foot container are forming this 10 meters high Lighthouse. Top container has two rotating beam headlights, while the ground floor container hosts an information office/gallery promoting port activities in the Paris region and river transport as an alternative to road transport.

Dieser mobile Leuchtturm wurde 2010 bestellt, um den 40. Jahrestag der Gründung des Pariser Hafens zu feiern. Hergestellt wurde er von Gérard Noirot und Jure Kotnik, slowenischer Architekt, der in seiner Arbeit Container benutzt. Die Tätigkeiten des Pariser Hafens sind zwar von der breiten Öffentlichkeit verkannt. Aber mit dem Transport von 20 Millionen Tonnen Ware und sieben Millionen Menschen auf dem Wasserweg ist der Hafen von Paris der bedeutendste Flusshafen Frankreichs und der zweitgrößte Europas. Es ging mit diesem Projekt um die Förderung des Flussverkehrs als nachhaltiges ökologisches Transportmittel. Die jährliche Transportmenge auf den Pariser Wasserwegen bedeutet eigentlich eine Million Lastwagen weniger auf den Straßen, nämlich eine Reduzierung von 200000 Tonnen der CO2 Freisetzung. Der aus Containern gebaute mobile Leuchtturm sollte eine symbolische „Beleuchtung“ dieser Tatsachen anbieten, indem er jeweils für drei Monate in fünf verschiedenen Hafenlandschaften an der Seine und an der Marne in Betrieb gesetzt wurde, und zwar in Évry, Limay, Paris, Gennevilliers und Bonneuil-sur-Marne. Der mobile Leuchtturm besteht aus zwei Grundbestandteilen des Hafens: der traditionelle Leuchtturm und die Container. Die Leuchttürme gehören zur allgemeinen Vorstellung des Hafens und des Wasserverkehrs. Die Container sind repräsentativ für die moderne Hafen- und Transportwelt. Sie erweisen sich auch als ein ideales Material für Eventarchitektur, denn sie sind leicht zu bauen, eben sowie von einem Ort zum anderen zu transportieren. Vier 20-Fuß-Container wurden also wiederverwertet, um einen zehn Meter hohen Leuchtturm zu errichten. Der obere Container bietet zwei Blinklichter. Am Erdgeschoss befindet sich ein Informationsbüro über Hafenaktivitäten in der Pariser Region und über den Flussverkehr als Alternative für Straßenverkehrsmittel. 